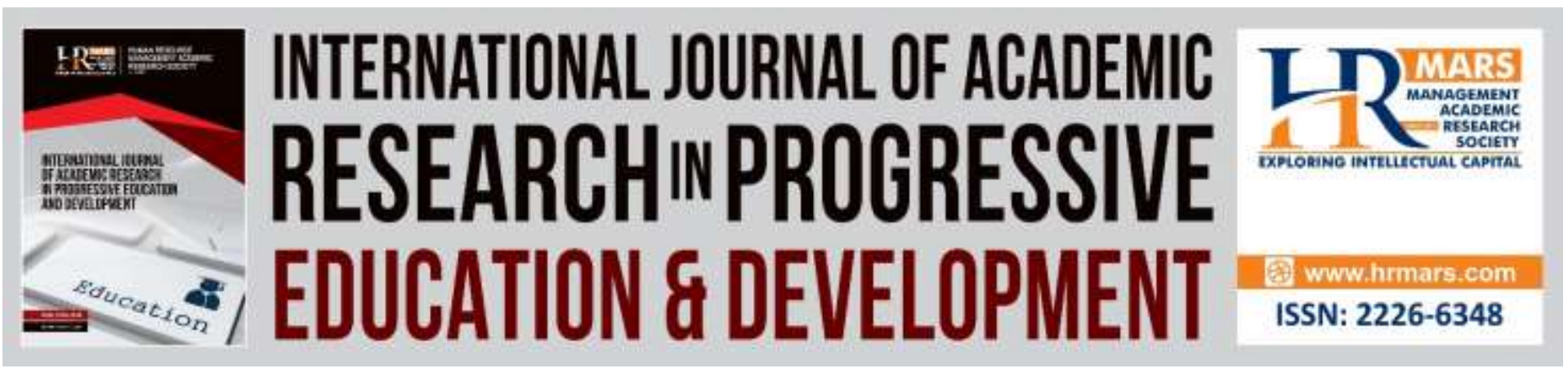

\title{
Students Athletes Academic Improvement through Time Management Skills A Case of University of Baghdad
}

Rawnaq Natiq Mohammed Ali Hamatani

To Link this Article: http://dx.doi.org/10.6007/IJARPED/v8-i2/5920

DOI: $10.6007 /$ IJARPED/v8-i2/5920

Received: 11 Jan 2019, Revised: 20 Feb 2019, Accepted: 10 March 2019

Published Online: 29 March 2019

In-Text Citation: (Hamatani, 2019)

To Cite this Article: Hamatani, R. N. M. A. (2019). Students Athletes Academic Improvement through Time Management Skills A Case of University of Baghdad. International Journal of Academic Research in Progressive Education and Development, 8(2), 472-484.

Copyright: (C) 2019 The Author(s)

Published by Human Resource Management Academic Research Society (www.hrmars.com)

This article is published under the Creative Commons Attribution (CC BY 4.0) license. Anyone may reproduce, distribute, translate and create derivative works of this article (for both commercial and non-commercial purposes), subject to full attribution to the original publication and authors. The full terms of this license may be seen

at: http://creativecommons.org/licences/by/4.0/legalcode

Vol. 8(2) 2019, Pg. 472 - 484

http://hrmars.com/index.php/pages/detail/IJARPED

JOURNAL HOMEPAGE

Full Terms \& Conditions of access and use can be found at http://hrmars.com/index.php/pages/detail/publication-ethics 


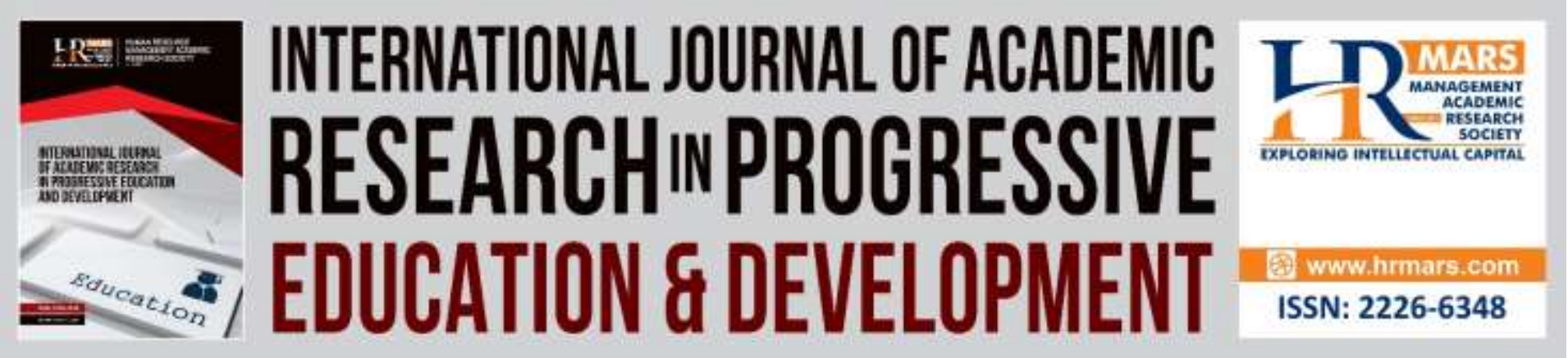

\title{
Students Athletes Academic Improvement through Time Management Skills A Case of University of Baghdad
}

\author{
Rawnaq Natiq Mohammed Ali Hamatani \\ College of political science, Nahrain University, Iraq
}

\begin{abstract}
The study is focused upon the student athlete improvement through time management skills in University of Baghdad. The participant selected for the study were the student athletes who have been enrolled in the Spring 2018 semester and had participated in at least in once in the sport activity and moreover they are registered for the Fall 2018 semester 100 participants were selected on the basis of the given criteria. For testing the stress level Sheldon Cohen's perceived stress scale was adopted. Cohen et al., (1983) developed this scale for measuring the perceived stress of individuals. The second variable was CGPA. The student CGPA data was collected from their respective faculties and department for two semesters i.e. spring and fall 2018. A paired sample ttest was utilized to test the hypotheses. Paired sample t-test are used to find out the differences in pre and post treatment results of same sample. For testing the two hypotheses. The significance level of 0.05 was used. The result shows the significant difference in stress level and academic performance of the student athletes before and after the time management skills workshop.
\end{abstract}

Keywords: Time Management Skills, Student Athletes, Stress Scale, Paired Sample T-Test

\section{Introduction}

Time management skills are highly important for the students in the current era because they are able to manage their studies and athleticism adequately. It is highly necessary for the students to use the time management skills in order to categorize their objectives and preferences through the time management system (Janse et al., 2011). Students are unaware about the value of time and become indulge in those activities that are being considered as the time consuming activities that impact upon their life and daily activities (Adebayo and Omojola, 2012). These activities are playing games, using social media, social engagement and others along with this most important feature is the athletics time is not also being taken. Therefore; the time management skills are highly necessary and effective for the students to become more evident and useful to manage their time and take time for the studies, sports and other activities of life (McDougle ad Capers, 2012). As far as the college students are already occupied with the activities and overload of the work and the 
students of medical sciences are having no time to make their activities manageable. This study will be helpful for the students manage their time for their studies and for the athleticism.

Time management is a complete science that includes different strategies, instrument and measures which enable an individual to increase the quality in their life. Those students that are athletes are require more space in their daily activities to manage their time and focus upon the studies as well. The study suggest that students that are having more centric towards managing their time able to get good grades in their academics (Janse et al., 2011). A study conducted on 293 first year student of psychology with the help of time management scale where students are being categorized on the basis of their age in three groups such as: students are being considered as the entry level having age less than 21 years; second group is the mature students that are under bracket age of 21 to 25 and third groups was older mature students that falls in the category of age more than 25 years (Trueman and Hartley, 1996). The findings of the study suggested that female students are more equipped with the time management skills as compare to the males at the entry level students as far as the older mature students are concern they are much better due to their age factor better than the overall groups that are considered for the study in their time management skills (Trueman and Hartley, 1996). Most of the previous studies have been done in the context of developed countries. So the current study is different in a sense that this study is contextually different and covers the scenario of a country which is not only under-developed but also much affected politically which has given stress to the population much. Moreover the previous studies have worked with very less number of respondents except the study done by (Trueman and Hartley, 1996). However they only covered the first year psychology students while the current study is more general in a sense that it covers the students from all years and from all departments.

The selected study is conducted in the context of University of Baghdad. Iraq's capital is Baghdad; they are overcoming the political regime has been changed and now government is focusing upon the infrastructure and other major issues that are required to be fixed. The study is based upon the students of the University of Baghdad regarding the Students Athlete Improvement through Time Management Skills. The purpose of this study is to undertake the perception of the university students that how they manage their sports activities and academics as well.

\section{Research Problem}

The study is focused upon the student athlete improvement through time management skills in University of Baghdad. Currently problem of the study is to develop the time management skills among the students in order to focus upon their studies and sports as well. The issue is that students are already occupied with their routine and it becomes difficult to manage time and that makes the issues in order to face the challenge to perform certain task mainly the academics and sports activities. However; researcher suggested that time is difficult to manage because there are different activities in a single day to manage everything according to the time and major issue is to resolve these issues with the help of time management skills. It is necessary for the students to develop their skills upon time management so they will be effective in their academics and sports as well. Therefore; this research is based in the context of Iraq where students are being analyzed upon the time management skills to manage their studies and sports adequately. 
INTERNATIONAL JOURNAL OF ACADEMIC RESEARCH IN PROGRESSIVE EDUCATION AND

DEVELOPMENT

Vol. 8, No. 2, 2019, E-ISSN: 2226-6348 @ 2019 HRMARS

\section{Research Questions}

Following are the research questions for the study:

1. Is there difference in the perceived stress level of student athletes of University of Baghdad before and after time management workshop?

2. Is there difference in the student athletes CGPA of the semester before and time management workshop?

\section{Research objectives}

Following are the research objectives for the study:

1. To identify whether there is any difference in the perceived stress level of student athletes of University of Baghdad before and after time management workshop.

2. To examine if there is any difference in the student athletes CGPA of semester before and after time management workshop.

\section{Literature Review}

Time management skills are considered as the issue resolving techniques that can be used by the students to manage study and sports. The study of Akomolafe (2015) suggested that time is difficult to manage because the pace cannot be slowed down, hold or produced. It is argued that time can be managed if the individual want to resolve the issue of being delayed in their activities it is mandatory for her or him to develop the time management skills (Grave, 2010). The whole universe is being managed through the time; everything happen on time and it cannot be delayed; so it is necessary for the human to consider time and valued it specially from the perspective of students because constructive use of time management enable them to perform in academics and in sports as well (Omolola, 2010).

It is evident that high school student's athletes are not having much responsibility but the college student athletes are considered more responsible for the academic performance. Athlete students of college are not paying attention towards the academic performance after getting the admission in the college the main reason is that they are highly focused upon their sports activities and want to develop their skills in it (McDougle and Capers, 2012). The university students are keen to get the academic performance rather than become more active in the sports. The college and university are allowing the students to participate in different sports event where they feel free to perform their athlete activities rather than at the schools. It is rather important for the students to focus upon their academic performance to become successful. For the students time management is considered as the biggest challenge to develop segregation between academic and sports activities (McDougle and Capers, 2012). Students are addictive towards performing the sports activities with more interest because the considered that they will become professional athlete but it is being argued that the ratio of becoming the professional athlete is very low.

Students are having mature age and in the university considered that their passion is to become the degree holder along with the athlete (Dalli, 2014). Those students that are not able to focus or manage their time adequately they are not able to achieve the academic performance. However; there are numbers of instances being observed that from the university or other institution there are few numbers of students athletes came into the profession and other remain unnamed in the profession of athletes (Junco and Cotton, 2012). It is suggested that academic performance is highly 
necessary because it shows ability to face the social challenges and eligibility. Education is the result of academic performance of the student and which being achieved through the objectives of educational guidance from their tutors. It is evident from the educational prospect that the eligibility of the student is being measured through the examination but there is no standard to test it and suggest what is important and which feature is necessary to assess the eligibility of the student (Adebayo and Omojola, 2012). Researcher argued that time management is the best solution to achieve the desired performance in academics. Students are required to develop the priority list which suggests them which objective is more essential to achieve first and followed it accordingly. Student's athletes felt mismanagement when the exams are near and they have to coup up with it to show better performance in the academics because they are not using the time management skills to overcome their burden of studies and sports simultaneously (Simon et al., 2015).

It is difficult to implement the time management strategies in the student life but prioritization makes them enable to feel peace and relaxation in their studies. The study was conducted in order to explore new ways of achieving the desired performance in academia. The study focused upon assessment of student time management and categorizing their priorities that impact on their final results (Macan et al, 2015). Those students are successful in the academic performances that are able to manage the time and able to prioritize their activities accordingly. Therefore; it is important that student should take proper classes and participate in the class discussion enable them to achieve the academic performance. As far as the athletes are concern they are not able to giver proper attention towards the academic performance because their motivation is the best and academic performance is not their priority which suggest their priorities are different as per the other non athletics students (Junco and Cotton, 2012).

Another study was conducted among the engineering university students in order to assess the traits and attitude which leads them to the average GPA from 3.24 to 4.0 scales (Miqdadi et al, 2014). The results of the study suggested that time management; prioritization and issue resolving features are the main factors in the study (Miqdadi et al., 2014). In the study student athletes are concern that are highly motivated and compassionate towards the achievement of their sports objective and performance; in their spare time they always associated with the professors and class fellows to perceive their guidance and assistance to meet the mandatory requirement in the academic performance (Miqdadi et al., 2014). It can be extracted from the previous studies findings that time management is the most important feature or indicator to attain the academic performance along with this it also includes that other activities and social engagement are also the part of the time management. The study conducted in University of California under the sample size of 6000 students that are enrolled in the undergraduate program; the results of the study suggested that there is no relation between the associating with the university activities and high advantages of education (Brint and Cantwell, 2010). The limitation of the student towards the academic performance is that doing job after the university timing. Students that are having job with their studies are being observed having low grades while other that are not involved in the job or sports having good grades and enjoying the high benefits of the educational activities. So it is suggested that priority and time management is the most important element to become successful to achieve the academic performance at the university level (Brint and Cantwell, 2010). 
For the athlete's student there are two important factors that include the academic performance in their viable season that are: time constraint and burden of performance both in the sports and in the education as well. Student athletes divided their time due to many reasons some of them are: education, sports training and practices, travelling, games, social life and family time (Simon et al., 2015). All together these factors are highly influential on the mind of student athletes. Moreover; the awareness of student athletes to handle the time limitations and meet the requirement of their sports and educational performance should meet the satisfied criteria. Due to that the student athletes are having problem with their academic performance when they are having their sports season (Miqdadi et al., 2014). It is evident that both side pressure such as: academic and sports make the individual ineffective and delayed in their allocated time period to pass out from the university or the institute. The more pressure is being built when the sports supervisors announce the eligibility of the athletes to be the part of the coming season that also led the student's academic performance down considerably (Kaushar, 2013).

In every sector of the market including the student athlete's time limitation is the main feature that led down the performance of the individual whether it is the sports field or the academic field (Perna et al., 2013). Student athletes are required to be more responsible towards time because they have to manage to major features that are academics and sports performance along with this there are other features as well that are associated with the life of them because the demand of class participation and team requirement are simultaneously that should be met accordingly (Janse et al, 2011). The pressure of being meeting the requirement of sports activities and academic performance that suggest student athletes should be having the effective time management skills. Travelling is the biggest limitation for the student athletes that also impact upon their performance in the academics when they are having the sports season. For the athlete it is not necessary to undertake which sports they are playing but for the purpose of sports activities they have to travel with their respective teams and for that they have to travel outside the cities that also create distraction and causing problem in their academics (McDougle and Caper, 2012).

Student's athletes are required to give their major part of time towards training and practices. The individual that are having major motivation in sports give their time towards the training session and gym which is not being considered as the practice time officially; which require energy and time to focus upon the other matters of life (Grave, 2010). The other feature that are associated with the problem of student athletes are the time they give to the sports activities, playing area, training and other sports related activities. It is a fact that most of the time student athletes are in the playing area and due to that excessive time is being given to the sports that reduce the time span for the studies as well. It is a fact that athletes are become tired of playing and taking training session which reduces their energy and that restrict them towards studying and preferring to take physical and mental rest (Miqdadi et al., 2014).

The findings of the different studies suggested that life the student athletes are very difficult because they are not able to give proper time to their studies and it is highly necessary for the athlete to manage time efficiently (Britton and Tesser, 2014). Athletes are having issue in giving proper attention towards sports so they give less attention towards the studies. They feel depressed because they have to perform at the sports field and in the academic as well which become difficult them to manage adequately. the performance of the student athletes is become a hurdle for them because they cannot focus on two thing sports or studies at a time therefore; 
sports have the priority because university or the institution is relying upon their performance in the sports field and expect high in order to make every possible effort to get success (Miqdadi et al, 2014). As far as the academic performance is concern they are not able to attend the lectures which is the biggest issue for them because lectures that are available on the university portal did not reflect the actual sense of learning or undertaking any subject because is it a one way communication in which theory is being delivered through it and the practical feature are missing that are being provided by the professor at the time of lecture which makes the subject or topic easy by sharing the example and question answers session ease the concept in the mind of the students. The pressure situation makes the student athlete to divert their attention which reduces their performance at the sport field and in the academics as well (Nsizwana et al., 2017).

This is evident that physical and psychological pressure increase the burden and anxiety among the student athlete which makes them ineffective and lack of motivation that require to be equipped through the time management skills through which they will be able to give proper time to their sports and academic as well (Junco and Cotton, 2012). The down performance is the result of lack of time management skills which increases pressure in their mind which reduces the efficiency into both areas of practices. The lack of interest in the pressure situation decreases the ability to think positively and unable to focus upon athletics and academics which cause them criticism from their respective coaches and professors. The pressure influenced upon the psychologically upon the student athlete which will make the individual emotionally down along with this it will lead to the damage of the immune system as well. Once the student athlete is having damaged immune system then it increases the probability of injury or lack of performance at the sports field (Perna et al., 2013). That will also lead towards the lack of performance in the academia because student is not able to distinguish which is important at what time; in other words; it suggest that student athlete is having lack of time management skills to manage their activities that are in the sports or academic field (Omolola, 2010).

The studies suggested that once the student athlete is having less chance to get injured or ill then it is increases the chances of the performance whether it is sports field or academic performance. With the constraints of stress and time that is being faced by the student athlete; there are different studies suggested the remedy which can be beneficial for the individual that is the time management skills and its strategies in their routine life which will develop the balance between their sports performance and academic performance as well (Britton and Tesser, 2014; Misra and McKean, 2015). The findings of the studies suggested that those students athletes that are taken the seminars on the time management skills are more measured and matured in managing their time rather than comparing to those they did not attend the seminar have the misbalance of approach in their time management (Macan et al., 2015). The study results showed that those students that have attended the workshop on the time management are more adequate in managing their time, having good grades, high graduation rate and low pressure in their life (Britton and Tesser, 2014).

The study of Britton and Tesser, (2014) based upon the survey that are being taken from the 90 students; the study was based upon two years findings that bring three major findings through it that are: majority of the passed out student considered that there is a need to improving the time management skills during the academic session. The second suggest that self approach towards time management will be effective in bringing the success in academic performance. The third 
finding was that those individuals that are having ability to perform but not able to give their best because they are not organized in their life therefore; they are not perform as compare to those that are having time management skills in their armory (Britton and Tesser, 2014).

Among the student athletes the issue prevailed that they are having high expectation to perform well in the sports and academic session as well; therefore; they are not able to coup up with the academic performance and fall in between where they are average in the academics and good in the athletics (Dalli, 2014). It is necessary that universities or the educational institutions should conduct the workshops or seminars that can facilities the student athletes for the time management skills for that they will be able to perform in both fields which is academics and sports accordingly. Time management skills are the most important feature that can increase the ability of managing the time by developing schedules and giving priorities to the activities that are necessary to performance on the daily basis (Kaushar, 2013). These skills are not only beneficial for the athletes but for the individuals as well that are focusing upon their academic performance. This feature leads the students whether they are athletes or not it will bring the stability and effectiveness in their life to manage their time according to the requirement of the situation and priority to perform certain actions adequately (Bakoban and Aljarallah, 2015).

\section{Research Hypothesis}

There is a significant difference in the stress level of student athletes before and after the time management workshop.

There is a significant difference in the CGPA of student athletes before and after the time management workshop.

\section{Methodology \\ Research Design}

The study is quantitative in nature as is aims to analyze the difference in CGPA of the student athletes and difference in the stress level of the student athletes before and after a time management workshop. Hence this design is a pretest-posttest design. The pretest-posttest design is employed when researcher is interested to know the group behaviors before and after any treatment. So here in this study the treatment is time management skills work shop.

\section{Participants Selection and Criteria}

The participant selected for the study were the student athletes who have been enrolled in the Spring 2018 semester and had participated in at least in once in the sport activity and moreover they are registered for the Fall 2018 semester 100 participants were selected on the basis of the given criteria.

\section{Data Collection}

The data was to be collected for the two variables i.e. the participants' stress level and CGPA. For testing the stress level Sheldon Cohen's perceived stress scale was adopted. Cohen et al (1983) developed this scale for measuring the perceived stress of individuals. It is a widely used instrument and measures the degrees to which an individuals are found to be stressed. The questions in the PSS ask about feelings and thoughts during the last month. In each case, respondents are asked 
how often they felt a certain way. The stress level data was collected twice once before the time management skills workshop and once after the workshop. The second variable was CGPA. The student CGPA data was collected from their respective faculties and department for two semesters i.e. spring and fall 2018.

\section{Data Analysis}

SPSS 21 was used to analysis the data. SPSS had been used in management (Eneizan et al, 2018a; Alsakarneh et al, 2018) in marketing (Eneizan et al, 2016; Eneizan et al, 2018b) in finance (Matar \& Eneizan, 2018) in educational studies (Adebayo and Omojola, 2012). A paired sample t-test was utilized to test the hypotheses. Paired sample t-test are used to find out the differences in pre and post treatment results of same sample. For testing the two hypotheses. The significance level of 0.05 was used. To analyze the data SPSS 22 was used.

\section{Results}

\section{Paired Sample T-Test for Stress Level}

\begin{tabular}{|c|c|c|c|c|c|}
\hline \multicolumn{6}{|c|}{ Paired Samples Statistics } \\
\hline & & Mean & $\mathrm{N}$ & Std. Deviation & Std. Error Mean \\
\hline \multirow[t]{2}{*}{ Pair 1} & Stress measurement after & 2.1570 & 100 & .27862 & .02786 \\
\hline & Stress measurement before & 3.1200 & 100 & .32349 & .03235 \\
\hline
\end{tabular}

\begin{tabular}{|c|c|c|c|c|c|c|c|}
\hline & & \multicolumn{3}{|c|}{ Paired Differences } & \multirow[b]{2}{*}{$\mathrm{t}$} & \multirow[b]{2}{*}{$d f$} & \multirow[b]{2}{*}{$\begin{array}{l}\text { Sig. (2- } \\
\text { tailed) }\end{array}$} \\
\hline & & Mean & $\begin{array}{c}\text { Std. } \\
\text { Deviation }\end{array}$ & $\begin{array}{l}\text { Std. } \\
\text { Error } \\
\text { Mean }\end{array}$ & & & \\
\hline $\begin{array}{l}\text { Pair } \\
1\end{array}$ & $\begin{array}{l}\text { Stress measurement } \\
\text { after - Stress } \\
\text { measurement before }\end{array}$ & -.96300 & .08367 & .00837 & $115.092^{-}$ & 99 & .000 \\
\hline
\end{tabular}

The above analysis test the $\mathrm{H} 1$ of the study: There is a significant difference in the stress level of student athletes before and after the time management workshop. The results in the first table shows that the average stress level was 3.12 before the time management workshop was held. The after the time management workshop the average stress level decreased to 2.15. All the questions in the stress management questionnaire were based on the scale from 0 to 4 . Where $0=$ never, $1=$ almost never, 2 = sometimes, 3 = fairly often, 4= very often.

The second table shows that the mean difference between the stress level before and after the treatment (time management workshop) had decreased. The t value of 115 which is well above the threshold value of 2 and the $p$-value of 0.000 which is less than 0.05 shows that this difference is significant which means the stress level of the student athletes had decreased after they have attended time management workshop. Which is evident that increase in time management skill in student athletes can decrease their stress level. Hence the $\mathrm{H} 1$ was found to be supported. 
INTERNATIONAL JOURNAL OF ACADEMIC RESEARCH IN PROGRESSIVE EDUCATION AND DEVELOPMENT

Vol. 8, No. 2, 2019, E-ISSN: 2226-6348 @ 2019 HRMARS

\section{Paired Sample T-Test for CGPA}

Paired Samples Statistics

\begin{tabular}{|ll|r|r|r|r|}
\hline & & \multicolumn{1}{|c|}{ Mean } & N & \multicolumn{1}{c|}{ Std. Deviation } & Std. Error Mean \\
\hline Pair 1 & CGPA Fall 18 & 3.2901 & 100 & .45733 & .04573 \\
& CGPA Spring 18 & 2.9391 & 100 & .49257 & .04926 \\
\hline
\end{tabular}

\begin{tabular}{|c|c|c|c|c|c|c|}
\hline & \multicolumn{3}{|c|}{ Paired Differences } & \multirow[b]{2}{*}{$\mathrm{T}$} & \multirow[b]{2}{*}{$\mathrm{df}$} & \multirow[b]{2}{*}{$\begin{array}{l}\text { Sig. ( } 2- \\
\text { tailed) }\end{array}$} \\
\hline & Mean & $\begin{array}{c}\text { Std. } \\
\text { Deviation }\end{array}$ & $\begin{array}{l}\text { Std. Error } \\
\text { Mean }\end{array}$ & & & \\
\hline $\begin{array}{l}\text { Pair } 1 \text { CGPA Fall } 18 \text { - CGPA } \\
\text { Spring } 18\end{array}$ & .35100 & .12665 & .01266 & 27.715 & 99 & .000 \\
\hline
\end{tabular}

The above analysis test the $\mathrm{H} 2$ of the study: There is a significant difference in the CGPA of student athletes before and after the time management workshop. The results in the first table shows that the average CGPA to be 2.93 in spring 2018 before the time management workshop was held. The after the time management workshop the average CGPA of the student athletes increased to 3.29 in fall 2018 semester. The CGPA of the students was based on 4 grade points.

The second table shows that the mean difference between the CGPA before and after the treatment (time management workshop) had increased. The t value of 27 which is well above the threshold value of 2 and the $p$-value of 0.000 which is less than 0.05 shows that this difference is significant which means the average CGPA of the student athletes had increased after they had attended time management workshop. Which is evident that increase in time management skill in student athletes increases their academic performance (CGPA). Hence the $\mathrm{H} 2$ of the study was also found to be significant.

\section{Discussion}

The study was aimed to understand that the time management skills can make difference in students CGPA and their Stress level significantly. For this two hypotheses were developed and the results suggested both hypotheses were supported significantly. Showing the significant impact of time management workshop on stress level and academic performance of the student athletes. The results are well aligned with the arguments given by (Britton \& Tesser, 1991). The results were also supported by another past study done by (Misra \& McKean, 2000). However the results contradicts with the study of (Owen, 2016) as he did not find any difference in stress level and academic performance of the student athletes on the basis of time management skills. However he explains the possible reason for that taking a small sample and taking the GPA of the student at the mid-point of the semester. However Misra and McKean (2000) found that positive time management skills increased academic performance. 
INTERNATIONAL JOURNAL OF ACADEMIC RESEARCH IN PROGRESSIVE EDUCATION AND

DEVELOPMENT

Vol. 8, No. 2, 2019, E-ISSN: 2226-6348 @ 2019 HRMARS

\section{Limitations of the Study}

The main limitation of the study was the workshop provided to the students as it was delivered only once. The better results would have been achieved if there had been a series of workshops. Moreover the study was limited to only one university in Baghdad. More universities may have been studied for the generalization of the results.

\section{Future Research}

The future research consideration for the study are inclusion of more universities from the same geographical context i.e. Iraq and a series for workshop should be provided to the students throughout the semester.

\section{Conclusion}

Time management skills are highly important for the students in the current era because they are able to manage their studies and athleticism adequately. It is highly necessary for the students to use the time management skills in order to categorize their objectives and preferences through the time management system (Janse et al., 2011). The study is focused upon the student athlete improvement through time management skills in University of Baghdad. For testing the stress level Sheldon Cohen's perceived stress scale was adopted. Cohen et al (1983) developed this scale for measuring the perceived stress of individuals. The second variable was CGPA. The student CGPA data was collected from their respective faculties and department for two semesters i.e. spring and fall 2018. A paired sample t-test was utilized to test the hypotheses. The result shows the significant difference in stress level and academic performance of the student athletes before and after the time management skills workshop. Conclusively it can be said that the time management skills play an important role in student athletes academic career and it is time management which can make difference in their academic performance.

\section{References}

Adebayo, F. A., \& Omojola, I. (2012). Influence of Time Management on Administrative Effectiveness in higher institutions in Ekiti State, Nigeria. International Journal of Educational Research and Technology, 3(1), 52-60.

Akomolafe, C. O., (2015). Principals Time Management abilities in higher education in Nigeria. Nigerian Journal of Educational Administration and Planning, 5(1), 58-67.

Alsakarneh, A. A. A., Hong, S. C., Eneizan, B. M., \& AL-kharabsheh, K. A. (2018). Exploring the relationship between the emotional labor and performance in the Jordanian insurance industry. Current Psychology, 1-12.

Bakoban, R. A. and Aljarallah, S. A., (2015): Extracurricular activities and their effect on the student's grade point average: Statistical study. Educational Research and Reviews, 10(20): 2737-2744

Britton, B. K., \& Tesser, A., (2014). Effects of Time-Management Practices on College Grades. Journal of Educational Psychology. 83(3), 405-410.

Cohen, S., Kamarck, T., \& Mermelstein, R. (1983). A global measure of perceived stress. Journal of health and social behavior, 385-396. 
INTERNATIONAL JOURNAL OF ACADEMIC RESEARCH IN PROGRESSIVE EDUCATION AND

DEVELOPMENT

Vol. 8, No. 2, 2019, E-ISSN: 2226-6348 @ 2019 HRMARS

Dalli M., (2014): The university students' time management skills in terms of their academic life satisfaction and academic achievement levels. Educational Research and Reviews, 9(20), 1090-1096.

Eneizan, B. M., Wahab, K. A., \& Abd Wahab, K. (2016). Effect of green marketing strategy on customer satisfaction in Jordan. Oman Chapter of Arabian Journal of Business and Management Review, 34(3403), 1-7.

Eneizan, B., Abdulrahman, S. A., \& Alabboodi, A. S. (2018b). The influence of environmental marketing mix on the non-financial performance of solar energy firms: The mediating role of corporate image. IJAR, 4(7), 190-196.

Eneizan, B., Mostafa, A. A., \& Alabboodi, A. S. (2018a). Effect of technical support and trust on the adoption of electronic human resource management: Evidence from developing countries. IJAR, 4(7), 31-40.

Grave B. S., (2010): The Effect of Student Time Allocation on Academic Achievement. Ruhr Economic Papers, 235: 4-23.

Janse van Rensburg, C., Surujlal, J., \& Dhurup, M., (2011). Exploring wellness practices and barriers: A qualitative study of university student-athletes. Ahysical activity, health and wellness. African Journal for Physical Health Education, Recreation and Dance, 17(2), 248-265

Junco, R. and Cotton, S. (2012): No A 4 U: The relationship between multitasking and academic performance. Computers \& Education, 59(2): 505-514

Kaushar, M. (2013): Study of Impact of Time Management on Academic Performance of College Students. IOSR Journal of Business and Management, 9(6): 59-60

Macan, T., Shahani, C., Dipboye, R., \& Phillips, A. (2015). College students' time management: Correlations with academic performance and stress. Journal of Educational Psychology. 82(4), 760-768

Matar, A., \& Eneizan, B. M. (2018). Determinants of financial performance in the industrial firms: Evidence from Jordan. Asian Journal of Agricultural Extension, Economics \& Sociology, 22(1), 1-10.

McDougle, L., \& Capers, Q. (2012). Establishing Priorities for Student-Athletes: Balancing Academics and Sports. Spectrum: A Journal on Black Men, 1(1), 71-77.

Miqdadi, F. Z, ALMomani, A. F, Masharqa, S. M. T. and Elmousel, N. M. (2014): The Relationship between Time Management and the Academic Performance of Students from the Petroleum Institute in Abu Dhabi, the UAE. ASEE 2014 Zone I Conference, April 3-5, 2014, University of Bridgeport, Bridgpeort, CT, USA., http://www.asee.org/documents/zones/zone1/2014/Stu dent/PDFs/177.pdf

Misra, R., \& McKean, M. (2015). College students' academic stress and its relation to their anxiety, time management, and leisure satisfaction. American Journal of Health Studies, 16(1), 41.

Nsizwana, S. C., Ige K. D. \& Tshabalala, N. G., (2017): Social Media Use and Academic Performance of Undergraduate Students in South African Higher Institutions: The Case of the University of Zululand. Journal of Social Sciences 50(1-3):141-152.

Omolola, A. D. (2010): Time management among the Nigerian undergraduates - A case study of University of Ado Ekiti, Nigeria. Unpublished Undergraduate Project. 
Perna, F. M., Antoni, M. H., Baum, A., Gordon, P., \& Schneiderman, N. (2013). Cognitive behavioral stress management effects on injury and illness among competitive athletes: A Randomized Clinical trial. Annals of Behavioral Medicine, 25(1), 66-73.

Simon, H. D., Van Rheenen, D., \& Covington, M. V. (2015). Academic motivation and the student athlete. Journal of College Student Development, 40, 151-162.

Trueman, M. and Hartley, J. (1996). A comparison between the time-management skills and academic performance of mature and traditional-entry university students. Higher Education, 32(2): 199-215. 